\title{
Ethnographic Accounts of Visitors from the Austro-Hungarian Monarchy to the Asian Peripheries of Russia and Their Contribution to the Development of Systematic Ethnological Studies in the Monarchy: Preliminary Results and Research Perspectives
}

\section{Csaba Mészáros - Stefan Krist - Vsevolod Bashkuev - Luboš Bělka - Zsófia Hacsek - Zoltán Nagy - István Sántha - Ildikó Sz. Kristóf}

Institute of Ethnology, RCH, Hungarian Academy of Sciences -

Center for Mongolian Studies, Innner Mongolia University in Hohhot, China Institute of Mongolian, Buddhist and Tibetan Studies, Russian Academy of Sciences, Siberia -

Department for the Study of Religions, Faculty of Arts, Masaryk University -

Department of Social and Cultural Anthropology, University of Vienna Department of European Ethnology and Cultural Anthropology, University of Pécs Institute of Ethnology, RCH, Hungarian Academy of Sciences Institute of Ethnology, RCH, Hungarian Academy of Sciences

\begin{abstract}
The authors intend to provide an overview of the diaries, travelogues, and correspondence of Austro-Hungarians who traveled to the Asian peripheries of Russia during the Dual Monarchy. We aim to contribute to ongoing discussions on colonial discourses of otherness, as well as to the historical development of ethnographic scholarship in Europe. Travel writing, orientalism, and colonial encounters with Asian otherness are closely intermingling phenomena in the modern era. We argue that the rich corpus of visual and verbal representations of North-, Central-, and Inner-Asian peoples recorded by the subjects of the Dual Monarchy provides instructive examples of colonial encounters with non-colonizers in $19^{\text {th }}$ century Asia. Furthermore, we believe that these examples will bring forth a more detailed picture of how the ideas born in the centers of German enlightenment (like Völkerkunde) impregnated the intellectual life of more peripheral regions in Europe. As ethnographic scholarship developed within national research traditions rather than in the frame of a monolithic, European intellectual project, our question is whether or not the Dual Monarchy provided a meaningful frame to bridge national research traditions.
\end{abstract}

Keywords: travel writing, orientalism, Austro-Hungarian Dual Monarchy, Siberia, Central Asia, history of ethnography 
Research on travel writing is an increasingly important topic in historical and anthropological scholarship (HUlme - Youngs 2002; KueHN - SMethurst 2009; PRATT 1992; Youngs 2006). By providing an overview of the diaries, travelogues, and correspondence of those Austro-Hungarians who visited the Asian peripheries of Russia, we aim to contribute to ongoing discussions on colonial discourses of otherness, as well as on the historical development of ethnographic scholarship in Europe. Travel writing, orientalism, and colonial encounters with Asian otherness are closely intermingled phenomena in the modern era (ANDREeva 2007; PhILlips 2014). We argue that the rich corpus of visual and verbal representations of North-, Central-, and Inner-Asian peoples recorded by travelers from the Dual Monarchy provides instructive examples of colonial encounters with non-colonizers in Asia in the $19^{\text {th }}$ century. The research question we pose is whether or not travelers from the Austro-Hungarian Monarchy and its predecessors, a unique political formation in Europe, had a distinct perspective on non-European peoples in the late $19^{\text {th }}$ and early $20^{\text {th }}$ century.

Our research points to a common shortcoming in determining who is a traveler. Commonly, a traveler is defined as a person who leaves home in order to gain something material or immaterial, or both, in another place (CLIFFord 1997:197). This implies that the traveler proceeds voluntarily. The overwhelming majority of travelers in our study, however, embarked on their journeys involuntarily; they were Austro-Hungarian prisoners of war (POWs) captured by the Russian army in WWI who had no say in where they were taken. Nonetheless, these prisoners saw the country and met its inhabitants as they were taken to Siberian camps, and when they left the camps to work. After 1918, not all prisoners could return home immediately following their release from captivity due to the Russian Civil War. It was during this waiting period that many saw and met more Siberians, and as a result, came to know the country and its people. These accounts are of special interest for our analysis, as are those from people who voluntarily stayed longer than needed - who made the transformation from involuntary travelers to voluntary residents. Thus, we juxtapose voluntary and involuntary travelers in our study.

In this article we would like to provide a rough overview of the research perspectives this vast material provides for historians and ethnographers. In order to do so, we first outline the position the Austro-Hungarian Monarchy held among the great European powers. We argue that the monarchy, with its multi-ethnic composition and lack of colonies overseas, was a unique point of departure for travelers in the late $19^{\text {th }}$ and early $20^{\text {th }}$ century. We then turn our attention to a region we call "the Asian peripheries of Russia", which was frequented by travelers from the monarchy for a number of reasons. Next, we provide a tentative classification of travelers and expeditions, and mention the written or visual records these travelers left behind. In order to provide a clearer picture of the peculiarities of travel records from the monarchy, we discuss two interlinked problems in the last chapters: the unique fieldwork and travel strategies such travelers used in Russia and beyond, and how socio-cultural backgrounds influenced the way they perceived, contacted and described non-European, indigenous peoples during their travels. 


\section{THE MONARCHY AS A MULTI-ETHNIC MIDDLE POWER LACKING COLONIES}

The Austro-Hungarian Dual Monarchy, from whence these travelers began their journeys, remained demographically a multi-ethnic, multi-lingual, and multi-religious state with no majority nations during the emergence of nation states (BUREAU 1912). ${ }^{1}$ From a legal point of view, the monarchy was a composite of pre-modern kingdoms with unbalanced power relations between nationalities that never transformed into a multinational state (BRUNNER 1962; HASSLINGER 2012). This inner structure resulted in vibrant and tense, cross-national and cross-regional relations. As a result, the political legacy of the monarchy was simultaneously considered a 'prison of nations' (Völkerkerker), as well as a flexible state forming a reasonably stable framework for the coexistence of various religious, ethnic and linguistic communities (Völkerverein) (WANDRUSZKA 1980).

Alongside other socio-economic factors, this inner tension limited the success of the monarchy's foreign policy, and led to a steady decline of its power within Europe (SKED 2001). Consequently, over the course of the $19^{\text {th }}$ century, when most European nationstates were attempting to establish overseas colonies, the Austrian Empire and later the monarchy, despite her colonial aspirations (BúR 2011; RANDA 1966; SAUER 2002), was preoccupied with maintaining its unity as well as consolidating its borders and position among European powers.

However, the Austrian Empire and its predecessor, the Holy Roman Empire, had its own colonial ambitions which, at least partially, followed earlier European patterns and orientations. By the $18^{\text {th }}$ century, worldwide organizations such as the "Ostendische Kompanie" (1722-1727) and the "Ostindische Kompanie Triest Antwerpen" (1775-1785), under the direct or indirect control of the Habsburgs, had come into being (CHAUDHURY 1999; MATHEW 1995). The Catholic religious orders, like merchants, provided a network for the long-distance transfer of knowledge and products (while at the same time, attempting to preserve the memory of the empire of Holy Roman Emperor Charles V [1500-1558]). The Jesuits, whose East-Central European/Austrian province was centered in Vienna, and whose most important regional academia (university) was founded in Nagyszombat/ Trnava/Tyrnau in 1635 (Sz. KRISTóF 2012, 2014), were of great importance. Yet, with the emergence of Great Britain and France as leading maritime (and principal colonial) powers during the $18^{\text {th }}$ and $19^{\text {th }}$ centuries, the explicit colonial efforts of the AustroHungarian Monarchy and its predecessors failed. Following some failed attempts in India along the Malabar Coast in connection with the activity of the Ostendische Kompanie, Austria's colonization of the Nicobar Islands did not last (1778-1783), and neither did their presence in Mexico (1864-1867) or North Borneo (1878-1880) (HASLIP 1971; SAUNDERs 2013). The Dual Monarchy held a concession zone in Tianjin, China for twenty years (1899-1919) (SzUK 1904). Certain efforts were made both in circumnavigating the earth (the Novara Expedition, 1857-1859), and in exploring the Northeast Passage (the Tegethoff Expedition, 1872-1874, finding and unofficially appropriating the "Franz Josef Land" from 1873 to 1926) (RIEDL-DoRN 2014; SCHEFBECK 2014). Austria-Hungary seems to have been successful, however, in one (internal) colonizing action: the occupation of

${ }^{1}$ The Austro-Hungarian Dual Monarchy was established by the 1867 Compromise. Until 1867, Hungary was a subject of the Austrian Empire, the succesor of the Holy Roman Empire. 
Bosnia and Herzegovina (1878-1918) (Diószegi 2001:121-125; Donia 2008). Whether the monarchy successfully made use of its experience in managing a multi-ethnic area in this colonial endeavor is a separate question.

With stable ethnic and linguistic divisions having evolved by the end of the $18^{\text {th }}$ century, the $19^{\text {th }}$ century gave rise to the birth of nationalism and national integrations ${ }^{2}$ in the region. The monarchy, however, retained a pre-modern character in its sociopolitical and economic structure; despite noticeable industrial development in the late $19^{\text {th }}$ and early $20^{\text {th }}$ century, agriculture remained its economic base. Shortly before WWI, "more than $60 \%$ of the people were employed in agricultural work while only $18 \%$ were employed in industry" (CULPIN - HENIG 1997:35). The dominant agricultural form of production remained "[m]anorial estates, owned by the nobility and worked by a servile peasantry" (MARKOVITS 1982:2). In this system - medieval by origin and character - 'national' identity rarely played a particular role for the peasants or the politically conservative, landed aristocrats who maintained an influential role in the political discourses of the empire none the less. Therefore, the urban, liberal bourgeoisie, as well as the factory workers, had a less influential role than their counterparts in the more modernized countries of Western Europe (MARKOVITS 1982:8).

The difference between Western and Eastern European nationalism is theorized in two different manners in historical scholarship. The first argues that as nationalistic passions universally spread more among townspeople than the rural population, nationalistic movements in Austria-Hungary were weaker than in other countries and had less chance to succeed. Furthermore, any demand by a nationalistic movement implicated discrimination of other nationalities, which was widely opposed in the monarchy, and, with the exception of the Magyarization policy in Hungary after the Compromise, could therefore not be pushed through (MARKOVITs 1982:8).

Other historians claim that the lack of an urban bourgeoisie (especially in Hungary) meant that any nationalistic movement initially supported by noblemen was expressed in a fairly exclusive and intolerant manner when it reached the less educated, rural population (see Woolf 1996:22-25). Furthermore, it is argued that this exclusivity fueled ethnic and national tensions within the monarchy, and eventually led to its disintegration after WWI.

The Hungarian nationality policy, for example, was determined by the question of independence from Austria and by the secessionist movements of minorities in Hungary (NAGY - Katus 2010; VARGa 2017:19). Consequently, political thinking in Hungary was permeated by two ideas: equality of civil rights within a territorially united and indissoluble state, and national supremacy that ensures the political prerogatives of the population professing to be Hungarian based on use of Hungarian as their mother tongue and self-identity (JÁszI 1929). Of the various contesting concepts of nation and the related nationalisms, linguistic nationalism came to determine the nationality policy, replacing the dominant hungarus identity ${ }^{3}$ (MeInecke 1908; Miskolczy 2012; SundHausen 1973). This implied Magyarization resulted in Hungarians gaining an absolute majority

\footnotetext{
${ }^{2}$ We use the term as defined by Bálint VARGA (2017:18-19). National integration took place at three different levels, but not in equal measure: the level of subjectness in the monarchy, at a Hungarian level, and at the level of other "nationality" cultures. (HoFER 1989:59-63)

${ }^{3}$ A form of identity based on territoriality by which the inhabitants of Hungary identified themselves.
} 
in Hungary by 1900 (DeÁK 2000; SzARKa 1998:33-73). The integration of other nationalities within Hungary continued at paces corresponding to their differing legal, religious and economic conditions. ${ }^{4}$

The question remains, whether or not this political situation and socio-economic milieu had a considerable influence on the scientific discourse of the monarchy's multinational intelligentsia, and if it added a unique perspective to its ethnographic discourses on oriental otherness that would translate racial differentiations into ethnic and cultural hegemony (AsH - SURMAN 2012:5-7; FUCHS 2003:154).

\section{THE ASIAN PERIPHERIES OF THE RUSSIAN EMPIRE AND THE DUAL MONARCHY}

Subjects of the Dual Monarchy travelled across the globe, but for the purpose of this study we target their travel to the Asian peripheries of the Russian Empire. Beginning in the $16^{\text {th }}$ century, the eastern and southern expansion of the Muscovite state (later Russia) created a large Asian territory under Russian rule and influence. It functioned in the modern era as the economic and social periphery of the Russian Empire (BASSIN 1991). This vast area includes Siberia, Central Asia, Inner Asia, Manchuria, and to some extent, the Caucasus. The importance of these peripheries cannot be overestimated in terms of Russia's history (BURBAnK et al. 2007; SAHADEO 2015), and the history of European ethnographic scholarship (VERMEULEN 2015). The blurred border between the colonies and the mainland, and between territories occupied by settlers and indigenous peoples, makes it difficult to separate the peripheries geographically from the center of the Russian Empire (SCHRADDER 2007), especially in the late $19^{\text {th }}$ and early $20^{\text {th }}$ century when the empire was still expanding.

This territory is of special interest for three reasons. First, it was the only non-European territory visited en masse by subjects of the Dual Monarchy. These visits occurred during and after WWI when soldiers of the $k . u$. $k$. Armee were taken prisoner by the Russian army. Historians calculate that between 1.6 and 2.1 million Austro-Hungarian became POWs in Russia (LeIDINGER - Moritz 1997; NACHTIGAL 1996; RACHAMIMOV 2002:38). By contrast, there were only an estimated 167,000 German POWs in Russia (RACHAMimov 2002:39). Austro-Hungarian POWs received decent, sometimes amicable treatment from their Russian captors, and often had contact with the local population (RACHAMIMOV 2002:46-47).

Captive Austro-Hungarians were placed in a variety of POW camps dispersed throughout the Russian Empire, including in its Asian peripheries. In East Siberia, large camps were located at Berezovka in the vicinity of Verkhneudinsk (later renamed UlanUde), on a cliff overlooking the Shilka River at Sretensk in Transbaikalia, and at Spasskoe in the Russian Far East (RACHAmimov 2002:93). The Berezovka camp was one of the largest POW camps in the Russian Empire with over 27,000 Austro-Hungarian POWs (Austrians, Hungarians, and Poles).

\footnotetext{
${ }^{4}$ On the connection between modernity and nationalism (see GeLLNER 2009).
} 
Officers were often separated from rank-and-file soldiers, with captive officers enjoying much better treatment than soldiers; they received a monthly salary and were not forced to work. The Berezovka camp, for example, was famous among captured $k . u$. $k$. Armee officers for its trade academy which offered courses that were accredited after the war. And, while enforced idleness was one of the worst conditions of Russian captivity for officers, POWs whose educational background or natural inquisitiveness prevented them from falling into desperate homesickness found ways to engage in activities with the local population. Written accounts from Hans Kohn, Edwin Dwinder and Heimito von Doderer show that their captivity opened up new possibilities for self-enhancement, language learning, ethnographic research, and self-discovery (GATRELL 2005:563). Of particular interest are the accounts of those POWs who remained in Russia after gaining their freedom - some married local women, found work, took part in the Civil War, or even did research, thus becoming voluntary travelers or even residents. However, such opportunities only became available after the war.

Among the POWs of the monarchy, the Czech and Slovak legionaries are unique for having been captured on the battlefield, deserting from the Austro-Hungarian army, or for enlisting in the legion from elsewhere. The first Czech and Slovak Legion got as far as Siberia, Manchuria and Japan (JAKL 2006; Zeman 1923, 1928). Unlike most other POWs from Austria-Hungary, these legionaries stayed outside the camps for quite some time, and thus had more opportunities to be in contact with the local population. Although they did not prepare for their travels in any way, their records on Siberia are of particular interest (BĚLKA 2009).

The second reason this territory is of special interest is because the monarchy was by no means a rival of Russia in Asia, and its subjects could visit Siberia, Central Asia and the Russian-controlled parts of the Caucasus without major restrictions. This was a result of the alliance between Russia and Austria until the Crimean War - together they defended the balance of the European powers as established in the Vienna Settlement, and in opposing nationalist and liberal political movements in Europe (BREULLY 2015:150). Despite tensions between Austria-Hungary and the Russian Empire in the Balkans from the late $19^{\text {th }}$ to the early $20^{\text {th }}$ century (DEMETER 2007; SKED 1979:119-121), among the European powers, Austria likely posed the least threat for Russia in its Asian endeavors.

Although some researchers, like the anglophile Ármin Vámbéry (1832-1913), were vehement opponents of the eastern expansion of the Russian Empire (VÁMBÉRY 1871), archival material shows that good scientific relations and close cooperation existed between Russian ethnographers and ethnographic institutes in Austria-Hungary. Between 1875 and 1925, Vasilii Vasil'evich Radlov (Friedrich Wilhelm Radloff) (1837-1918), director of the Kunstkamera, and Sergey Fyodorovich Ol'denburg (1863-1934), chairman of the ethnographic division of the Russian Geographical Society, corresponded intensively with colleagues all over the world, including numerous scientists in Austria-Hungary. ${ }^{5}$ At the beginning of the $20^{\text {th }}$ century, the Russian Museum, a center of ethnographic research in Russia, sent the artifacts of an entire exhibition on fishery to Vienna. ${ }^{6}$

\footnotetext{
${ }^{5}$ Saint Petersburg's branch of the archive of the Russian Academy of Sciences, fond 177, opis' 1, and fond 208, opis' 2 .

${ }^{6}$ Archive of the Russian Museum of Ethnography, fond 1, opis' 2.
} 
Furthermore, some Russian and Austrian noble families were related. For instance, György Almásy (1867-1933), the leader of two expeditions to Central Asia in 1900 and 1908, married Vera Apraksina, who came from a Russian aristocratic family. ${ }^{7}$ Likewise, representatives of noble Hungarian families resided at the Tsarist court, like Count Mihály Zichy (1827-1906), who resided and worked in Saint Petersburg for nearly 50 years in the second half of the $19^{\text {th }}$ century.

The third reason why Russia's Asian peripheries were often visited by travelers from the monarchy and why it is of interest here is the notion of the Hugarians' oriental origin, an idea that was widely accepted in Europe in the late $19^{\text {th }}$ century. Two major (and somewhat interrelated) scholarly legacies dominated this discourse in the AustroHungarian Monarchy. The first relied on the testimonies of early medieval chronicles referring to Hungarians as the relatives of the Huns (GYÖRFFY 1993). The second was based on language comparisons from the $17^{\text {th }}$ century that point out lexicological and morphological parallels between the Finnish, Saami, and Hungarian languages (HeGEDüs 2004; STIPA 1990). In Hungary, the latter legacy was strongly influenced by linguistic, and the emerging ethnological (Völkerkunde) (VERMEULEN 2015) scholarship coming out of Georg-August University of Göttingen (FuTAKy 2007; MunKácsi 1882), where many leading Hungarian scholars had studied. Interest in the East - as a form of political resistance against the Catholic Habsburgs by the Hungarian nobility who were leading the national awakening movement (ANDERSON 2006:66-77, 92-97; SugAR 1969) focused on the period prior to Hungarian settlement in Central Europe. This romantic affection for the East often imported modern, Western orientalism, and attempted to locate the predecessors of Hungarian culture in the great cultures of the East. ${ }^{8}$ Underlying the different origin hypotheses were social (nobility vs. plebeians) and scientific (cultural psychology vs. positivist science) differences (HoFER 1989:63-66; HoNTI 2010, 2012; PusZTAY 1977, 1985; RóNA-TAS 1978; SzÜCs 1985; VÁRKONYI 1973:372-375, 400-409). According to subsequent rumors published in Hungarian journals in the $19^{\text {th }}$ century, Hungarians were not only of Asian origin, but their ancestors still resided in their Urheimat (TARDY 1975). These rumors resulted in public calls to carry out expeditions to Asia (K. D. 1821). Very few travelers (e.g. Sándor Körösi Csoma and Antal Reguly) managed to conduct fieldwork in Asia before the 1867 Compromise, but thereafter, the number of expeditions significantly increased.

\section{WHO WERE THE TRAVELERS FROM THE DUAL MONARCHY?}

As previously stated, many of the travelers from the Dual Monarchy reached Siberia and Central Asia, and the records they left behind on the inhabitants of Asia are of varying quality and length befitting the various scientific and social backgrounds of their authors. In order to classify this heterogeneous corpus of written and visual representations, we

\footnotetext{
7 István Sántha’s interview with Gyömörey Zita, Almásy György’s granddaughter in Vienna, 2008.

8 On the appearance of Western-type orientalism in architecture and decorative arts see F. Dózsa 1996, István 1996, and the most comprehensive overview by STAUD (1999). On the connection between orientalism and folklore see HOFER 2009, and HUSZKa 1900.
} 
propose a tentative classification of travelers (based on their socio-economic statuses and scientific backgrounds) rather than ordering these sources according to genre. Also, for the sake of comparison, we juxtapose rather than separate the records of Austrian, Czech, Hungarian, and Polish travelers.

\section{A.)}

The first group of travelers consists of professional researchers who visited the Asian territories of Russia to create ethnographic records. It is no surprise that the overwhelming majority of these travelers were Hungarian. Antal Reguly (1819-1858) visited Western Siberia, which was inhabited by Finno-Ugrian groups, in 1843-46 to prove their kinship with Hungarians. ${ }^{9}$ Twenty years after Reguly's expedition, the Hungarian Academy of Sciences financed Ármin Vámbéry's visit to the alleged Hungarian homeland in Central Asia. During Vámbéry's travels he visited the independent Khanates of Khiva and Samarkand disguised as a Sunni dervish (VÁMBÉRY 1865). These highly influential research trips not only resulted in fierce academic debates on the origin of the Hungarians, but also paved the way for further exploratory travel in Central Asia and Western Siberia.

The next generation of travelers followed either Reguly's footsteps or Vámbéry's vision of the origins of the Hungarians. The Hungarian Academy of Sciences asked Bernát Munkácsi (1860-1937) to decipher Reguly's Mansi collection. ${ }^{10}$ Munkácsi asked Károly Pápai (1861-1893), a scholar well versed in anthropological and ethnographic studies (MUNKÁCSI 1889:206-211), to accompany him. Their 16-month expedition took place in 1888-89. Munkácsi spent most of his time among the Mansi, but also carried out field research among the Khanty (KÁLMÁN 1981; KozMÁcs 2012; MunKácSI 1889; MunKácSI 1943; SIPŐCZ 2010). Pápai toured the areas populated by the Mansi and Khanty, but also did research among the Selkups and Komi (NAGY 2012; PÁPAI 1888, 1889, 1890, 1891).

At this point we should mention the role of aristocratics in organizing scientific expeditions to the Orient. Count Jenö Zichy (1837-1906) conducted several extensive research trips in Russia at the end of the $19^{\text {th }}$ century. He was a patron of and donor to expeditions in which archaeologists, ethnographers and zoologists worked. Alongside travelogues written under his name, a series of scientific books was published in which the results of these expeditions were presented. Among others, József Pápay, János Jankó, Gábor Szentkatolnai Bálint, Mór Wosinszky, Lajos Szádeczky-Kardoss, Béla Pósta, and Ernő Csiky took part in his subsequent expeditions. On his last expedition, in 1900, Count Zichy traveled through South Siberia, Mongolia and North East China to Beijing in order to seek out books on the ancient Hungarians allegedly written in the Roman alphabet at the imperial library.

\footnotetext{
${ }^{9}$ Reguly visited nearly every Finno-Ugrian group and did research among the Finns, Estonians, Saami, Mari, Mordvins, Udmurts, Komi, Nenets and Nganasan, but was mainly interested in the Mansi and Khanty. He also collected oral poetry and linguistic data among the Chuvash - then thought to speak a Finno-Ugric tongue - and the Tatars. On Reguly's travels see BALASSA 1954; HaJdú 1953; KodOLÁnYI 1959a, 1959b; KOROMPAY 1971; PÁPAY 1905, 1906; SzíJ 2009, 2013; TOLDY 1850.

${ }^{10} \mathrm{He}$ was not chosen at random; he had toured the areas inhabited by the Udmurts in 1885 and published several publications regarding this trip (MunKáCsI 1883; 1887a; 1890-1896). On his journey in Udmurtia (Kozmács 2010; MunKáCSI 2008). On his research among the Chuvash as part of this expedition (MunKáCSI 1887b). On Reguly's importance for the expedition (MunKácsi 1889:207208; PÁPAI 1890:117-118) and on his impact upon subsequent research (PÁPAY 1905).
} 
By 1877-78, the members of Count Béla Széchenyi's (1837-1918) research expedition had already spent nearly 14 months in China. Széchenyi had been working with the Austrian geologists Ferdinand von Hochstetter and Eduard Suess from the 1870s onwards. Inspired by their work, Széchenyi planned a comprehensive journey across British India, Japan and China to reach the southernmost part of the Gobi desert. He invited Gustav Kreitner (an Austrian geographer), Lajos Lóczy (a Hungarian geologist), and Gábor Szentkatolnai Bálint (a Hungarian linguist) to participate in this expedition.

The Almásy family, who had a long-standing interest in oriental studies (three generations), also carried out research trips. György Almásy's father, Eduard Almásy, was a founding member of the Hungarian geographical society. In 1900 György Almásy traveled to Kirghizia with the Austrian zoologist Rudolf Ritter von Stummer-Traunfels (Almásy 1903:13-14). He returned there in 1906 with Herbert von Archer, a friend of Austrian-Irish origin, and Hungarian geographer Gyula Prinz (1882-1973). Almásy collected Kirghiz heroic epics, and in 1906 he returned to Hungary with an indigenous research assistant, Turgan, who resided with Almásy for three years. ${ }^{11}$

A number of ethnographic expeditions carried out by subjects of the monarchy were financed by foreign patrons or research institutions. Ujfalvy Károly Jenö/CharlesEugène Ujfalvy de Mezőkövesd (1842-1904) led several research trips to Central Asia that were financed by the French Academy, and his field notes and research results were published in French ${ }^{12}$ (Ujfalvy 1878-1880). Aurél Stein (1862-1943) of Budapest was one of the most influential explorers of his age. The expeditions he carried out between 1900 and 1930 in Inner Asia were done in the service of the British Empire. He published several volumes on his journeys and discoveries, and most were translated into Hungarian shortly thereafter (STEIN 1909). The Smithsonian Institution commissioned Aleš Hrdlička (1869-1943), a Czech, to travel to Russia and Mongolia between 1912 and 1920 (see SPENCER 1979). His travelogues and travel correspondence are kept in the archive of the Smithsonian Institution (MONTGOMERY - CHIEN 2006).

\section{B.)}

A second group of travelers did not directly participate in or finance scientific expeditions. These travelers usually earned their living selling Oriental artifacts to European museums and by giving lectures in their home countries or elsewhere. Hans Leder, an AustrianSilesian entomologist (1843-1921), visited the Baikal region in 1891 to collect insects, primarily for the Court Museum in Vienna. He was a member of the Russian Geographical Society and cooperated with the newly founded museum in Kyakhta (at the RussianChinese border). In May of 1892 he set off from Kyakhta for his first journey to Mongolia, which lasted through August of that year. He later undertook three more journeys in 18991900, 1902, and 1904-05, each taking him through Siberia. During his first journey to Mongolia he became interested in Buddhism and began collecting, in addition to insects, Buddhist devotional objects, of which he sold many to museums in Austria-Hungary and Germany (to the Court Museum in Vienna and the ethnographic museums of Budapest,

\footnotetext{
${ }^{11}$ István Sántha’s interview with Zita Gyömörey, György Almásy’s granddaughter, in Vienna in 2008.

${ }^{12}$ Interestingly, his books have not been translated into Hungarian. However, the travelogue of his wife (who was French) was published in Budapest in 1885 (UJfaLvy-BOURDON 1885).
} 
Leipzig, Hamburg and Stuttgart). He also travelled to the Altay region in 1900. He gave numerous lectures in Germany, published roughly twenty articles and one book (LEDER 1909), and became a distinguished expert on Mongolian Buddhism. (LANG 2010; Leder 1908; Jisl 1963; ОтсHет 1891:10; ОтсHет 1892:15-18; Romanov 1993:232, 261, 450).

Josef Troll, of Vienna, was another traveler who made his living collecting ethnographic objects and selling them, mostly to the Court Museum. Troll traveled through the Baikal region in 1885 and 1893. Later in 1893 he also journeyed through Mongolia (ÖFNER 2011:18-19).

Josef Kořenský (1847-1937) was a Czech elementary school teacher and a highly systematic traveler; before setting off on a journey he studied the available literature in detail and tried to follow a prepared itinerary. Kořenský made two trips around the world: the first in 1893-1894, and the second in 1901, which included a trip through Siberia on his return to Austria-Hungary from Japan (KořENSKÝ 1910). Kořenský traveled on a postal steamboat up the Amur, and by train along the Trans-Siberian railway. He published several books about his journeys. The income he earned from his published books, as well as royalties and paid public lectures, provided most of the funding for his travels (KOǨENSKÝ 1920). His collection of travel photos is preserved in the Náprstek Museum of Asian, African and American Culture in Prague (see Todorovoví - CHOvanečEK 2011).

Benedek Baráthosi Balog (1870-1945), a Hungarian, was a school teacher and one of the leading activists of the international Turan movement (see e.g. KIss 2015; Ormos 2012; PAIKERT 1914). Between 1903 and 1914 he undertook expeditions to Russia and China where he worked as a semi-professional ethnographer and linguist. He traveled in the Amur region and to the islands of Sakhalin and Hokkaido to investigate local indigenous peoples. He collected small wooden ritual objects (amulets) for the leading European museums (Budapest, Hamburg, and London) in return for their financial support of his journeys (KoHARA - WiLHELM 1999). Following the October Revolution, the Bolsheviks confiscated a collection which he had left with his colleague, Professor Vladimir Klavdiyevich Arsenyev, at the local historical museum in Khabarovsk (BARÁTHOSI 1929). Pieces collected by Baráthosi seem to appear in both the collections of Khabarovsk and that of the Kunstkamera in Saint Petersburg.

Finally, the Imre Sebök-Aurél Schultz Expedition was organized to study the shamanic rituals of the Buryats in the Cisbaikal region, and to conduct economic and anthropological research among them (KISS 2015:16-17; PAIKERT 1914:5-6).

C.)

As previously mentioned, a number of Hungarian aristocrats traveled to Asia to carry out self-organized, scientific research expeditions. Other aristocrats, however, crossed Siberia and Inner Asia without any clear, scientific target. Two of the earliest travelers to that area were the Hungarian noblemen József Zichy (1841-1924) and his younger brother, Ágost (1852-1925). After navigating through the Dutch East Indies and Japan, they crossed Mongolia and Southern Russia from east to west. József kept a private diary during their travels (1876-77) (ZICHY 2013). As he had no scientific ambitions, he did not intend to publish the manuscript (SLOBODNí 2012). His younger brother, Ágost (later a member of the Hungarian Academy of Sciences), however, published two short travelogues in leading Hungarian journals about their trip (ZICHY 1877, 1880). József Zichy was not interested in finding the Oriental ancestors or ancient homeland of the 
Hungarians, but focused primarily on economic concerns. Attila Szemere (1859-1905), an art collector, visited Japan and China between 1881 and 1884. He did not publish scientific papers, but his travel correspondence and manuscripts are kept in the archives of the Otto Herman Museum in Miskolc, Hungary (Wintermantel 1999). Count Péter Vay (1863-1948), a protonotary by papal decree, crossed Siberia in 1904 and 1917 on his way to Japan and Korea (VAY 1906; 1918). He, like other lone aristocrat travelers, did not express much interest in the origins of the Hungarians, but, according to his travel books, rather focused on local social and economic conditions.

The Austrian Erich Pistor (1873-1954), a lawyer by training, was a member of the Chamber of Commerce in his hometown Graz, and later in Vienna. In 1901 he undertook a two-year journey through Siberia, Finland, Mongolia, Japan, China, Australia, and New Zealand. He subsequently published his travel notes (PISTOR 1905), a mixture of a diary and economical notes. His main task, as a correspondent of the k. u. k. Ministry of Commerce, was to explore the markets, economic trends, and possible import-export opportunities between these countries and Austria.

\section{D.)}

A fourth group of travelers ventured to the Asian parts of Russia seeking employment. The itinerary of Jan (Eskymo) Welzl (1868-1948), a Czech traveler, is rather dubious; it is hard to describe or trace his exact route of travel, but it is likely that he reached the Arctic Ocean and worked there on a merchantmen among Chukchees and Siberian Yupiks. He never published an article about his travels, but a manuscript known to have been written by him appeared in German, "An der Reise um die Welt 1893", and was published half a century after his death by Rudy Krejčí, in Czech (KREJČí 1997).

In 1898 Jenö (Eugene) Cholnoky (1870-1950), spent more than three months visiting silver and gold mines in Manchuria under the employment of a French mining Company (CHOLNOKY 1900:93). Later, he worked as a professor of geography in Kolozsvár/ Klausenburg/Cluj and was a founding member of the Hungarian Turanian Society. His travelogue combines elements of a diary, cultural study, and scientific analysis focusing on geomorphological questions (CHOLNOKY 1900:147, 167).

The Hungarian engineer, Károly Gubányi (1867-1935), was employed by the Russian state as a constructor-engineer at construction sites along the Eastern Chinese Railway (the Russian Manchurian railway). Gubányi lived in Manchuria between 1898 and 1903. His travelogue focuses on the resolution of technical problems of railway construction and operation due to local, natural and social circumstances (GUBÁNYI 1907).

\section{E.)}

As previously mentioned, of all of the Austro-Hungarian subjects who traveled to the region, the largest group consisted of involuntary travelers, WWI POWs. More than a few Austro-Hungarian POWs captured by the Russian army voluntarily stayed in Siberia longer than was necessary. Some, usually those who married local women, never left. Preliminary archival research shows that in the Catholic church of Verkhneudinsk (UlanUde) alone around eighty such marriages took place between 1918 and $1923 .{ }^{13}$

\footnotetext{
${ }^{13}$ State Archive of the Republic of Buryatia, fond 526, opis' 1, delo 3.
} 
Reinhard Augustin, a German-Bohemian born in 1896, was a POW from the AustroHungarian army who married a Russian. He became interested in ethnography whilst in Siberia and worked as a librarian in the regional museum of Khabarovsk until the Russian Civil War forced him to flee. Afterwards, he worked as a German and English language teacher in Kharbin and Manzhouli in Manchuria. In 1923, together with his wife, he moved to Austria and studied ethnology at the University of Vienna. In 1928 he obtained his doctorate with a dissertation on the traces of matriarchy in Northern Asia (Augustin 1927). ${ }^{14}$ From 1926 until the early1930s he worked in the library of Pater Wilhelm Schmidt's Anthropos-Institut in Mödling, practically the Austrian center of Völkerkunde at that time. There he published book reviews in the institute's journal, Anthropos, and translated the works of Buryat ethnographers into German. In the mid1930s he published two books (AUgustin 1934, 1936) and several articles of a semiautobiographical and semi-fictional nature - parts of which were clearly plagiarized from Vladimir Arsenyev's books - about 'his' experiences in Siberia and Manchuria.

Some POWs, like Franz Zupan (or Supan) from Temesvár/Temeschburg/Timișoara and Julius Eidler (or Aidler) from Ödenburg/Sopron, stayed and worked as medics helping the locals with their medical training until the late 1920s (Zupan/Supan) (WiLmanns 1995:93-94) or early 1930s (Eidler/Aidler) ${ }^{15}$ Robert Pollitzer was a wellknown epidemiologist of Austrian origin who specialized in diseases such as plague and cholera. Born in Vienna in 1885, Pollitzer graduated from the University of Vienna as a pathologist. He was captured in WWI by Russian troops and spent several years as a POW in Siberia. In 1921, he was invited by the world-renowned Chinese epidemiologist Dr. Wu Lien-teh (1879-1960) to work at the Manchurian plague control station (founded in 1912). Dr. Pollitzer became the first Russian-speaking researcher at the plague control station (RATMANOV - ZHANG Fengmin 2015:104). He actively published studies on epidemic diseases such as plague, cholera and tularemia after WWII. He wrote monographs on plague and cholera for the World Health Organization (PolLITZER 1954; 1959), monographs on plague and plague control in the USSR (PolLITZER 1966), and tularemia (Pollitzer 1967).

An abundance of photos and travel diaries taken and written by legionaries are preserved in various Czech and Slovak archives. ${ }^{16}$ Of all the POWs, only members of the Czech legion were free to take photos and keep diaries in Siberia. Furthermore, they were allowed to take these records home. Yet, in this wealth of material, only relatively few photos capture the various aspects of Buryat Buddhism: monks, lay people, their cult structures, temples, temple complexes and interiors, e.g. altars (BĚLKA 2011) - thus capturing the state of Buryat Buddhism prior to the Bolshevik revolution.

Two Hungarian officers, Ervin Bokor and József Ballay, fell into captivity as early as 1914. They were transported to Tomsk, from whence they escaped in 1915 to Manchuria, China and Japan. By 1916 they had returned to Vienna and were interviewed by Austrian and Hungarian journalists about their adventurous travels. In 1919, Ervin Bokor

\footnotetext{
${ }^{14}$ Archive of the University of Vienna, Nationale 1923-1928; archive of the Austrian National Library, Protokollzahl 819/1929.

${ }_{15}^{15}$ State Archive of the Republic of Buryatia, fond 563, opis' 1, dela 3, 4, 11, 12, 18.

${ }^{16}$ For details and an overview see ORIÁN 2014.
} 
published a memoir about their escape (BоKOR 1919). ${ }^{17}$ The book gained tremendous popularity and was reprinted in 1929 .

\section{TRAVEL STRATEGIES UTILIZED BY THE SUBJECTS OF THE DUAL MONARCHY IN RUSSIA AND BEYOND}

A number of travelers from the monarchy left ethnographic accounts of the non-European peoples they encountered in the Asian peripheries of Russia. It is therefore important to mention the factors that enabled and assisted their successful travel to and within Russia.

First, as previously stated, despite the rather uncertain relationship between the Austro-Hungarian Monarchy and Russia - the status of the Poles and Ukrainians was a constant source of conflict, as was that of the Balkans - travelers from the monarchy rarely, if ever, were seen as suspicious, dangerous agents of a foreign, colonial power by the Russian authorities. They neither posed a danger for the Russian colonizers, nor for the subordinated indigenous peoples. For example, Gubányi was trusted to contribute to the construction of a strategically important railroad, showing that top Russian bureaucrats considered him harmless (GUBÁNYI 1907:10-11). However, this attitude only prevailed in Russia; Europeans were often suspected of espionage among Asians in Japan and China (BARÁTHOSI 1927:27-28).

The position of Hungarian travelers (somewhere between colonizers and indigenous peoples) enabled them to maintain more or less equal standing among the indigenous peoples in Asiatic Russia. Hungarian travelers preferred to make use of their knowledge of local languages, to exchange objects, or adopt local habits in local contexts (BARÁTHOSI 1927:122-133; COUNT JENő ZiCHY 1905:86-88; Forbáth 1934:19-25; GUBÁNYI 1907:10-11). They learned from both local state bureaucrats and indigenous peoples during their travels (BARátHOSI 1927:122-133; GuBáNYI 1907:10-11). The establishment of relationships of an equal footing with local indigenous people, however, was only upheld temporarily and without permanent consequences. These relationships made Hungarian travelers uncomfortable, and once the relationship proved useful in resolving an immediate (emergency) situation, they no longer continued them or sought them out (BARÁTHOSI 1927:122-133; FORBáTH 1934:19-25).

In order to win the support of local authorities, Hungarian travelers often claimed to be searching for ancient ancestors and the homeland of the Hungarian people. They explicitly distinguished themselves from other European travelers who might have religious or business interests in the region. At the same time, they ensured the indigenous peoples that they did not act on behalf of the Russian state (JANKó 2000). When Béla Széchenyi was granted an audience with the Manchu prince of the Qing dynasty, he asked for a permit to visit Mongolia and Tibet. In his request he explained that his interests in crossing China were neither religious nor political, but purely scientific, historical, and even pious as he intended to visit the graves of the ancestors of the Hungarians and pray for the Hungarian nation (SZÉCHENYI 1890:xix-xxi).

\footnotetext{
${ }^{17}$ Other memoirs (CzIRA 2006; STOFFa 1935) show that many POWs fled eastward from Russian captivity. There may be more unpublished, latent manuscripts in German, Hungarian and Czech archives written by escapees who encountered indigenous peoples in Asia.
} 
During his meagerly financed, first field trip among the Udmurts in 1885, Munkácsi often depended on the goodwill and support of Russian bureaucrats, priests, or ethnographers. In order to win their support he asserted his intentions to find the relatives of the Hungarian nation (MuNKÁCSI 2008:73-74, 93). He received their support, as Pápai points out in his report, because members of Russian academic circles found it selfevident that Hungarian researchers would want to study their Siberian relatives, and therefore supported their expeditions (PÁPAI 1888:623-624).

József Geleta, a Hungarian POW (1885-1961), also benefitted from the notion of the oriental origin of the Hungarians; when he needed to acquire a permit upon entering Mongolia he mentioned the brotherhood between Hungarians and Mongolians to the Mongolian chief officer. When the officer discovered that Geleta was not a Russian, but Manchar, a European who was thereby not only a 'good man', but also a member of a sister race, he eventually granted the permit (FORBÁTH 1934:19-25).

Travelers from the monarchy built up a base of contacts through academic circles; many researchers from Austria-Hungary, especially the Hungarians, realized the elementary importance of Russian research. ${ }^{18}$ Furthermore, their Russian colleagues received them with sympathy. ${ }^{19}$ Antal Reguly became greatly popular in St. Petersburg and enjoyed the backing of Russian academic circles. ${ }^{20}$ As a result, Hungarian researchers maintained intense correspondence not only with Finnish, but Russian colleagues as well (BALASSA 1952; JANKó 1900b 1993; KodoláNYI 1993; RÁsONYi 1962; RusvaY 2005:91-98). This led to the support of two expeditions by Munkácsi and Pápai, and Jankó and Pápay. ${ }^{21}$ Munkácsi and Pápai's expedition was closely followed in Russia by distinguished scientists, which is particularly surprising in light of the vicissitudes Munkácsi endured in Udmurtia. ${ }^{22}$ They received letters of credence to aid their travel, and Pápai was invited to join his Russian colleagues on an expedition to the Urals too. ${ }^{23}$ Russian research institutions made bids to purchase his ethnographic objects (PÁPAI 1890:119). Jankó and Pápay also enjoyed the hospitality of Russian scholarly circles, as did Zichy's entire third expedition. ${ }^{24}$

${ }^{18}$ Note Jankó's statement: "His excellency Count Jenő Zichy was right in saying in his report that we had to discover the Russian literature, not the Russian Empire on our trip." (JANKó 1900a:29).

${ }^{19}$ For instance, Hans Leder was a member of the Russian Geographical Society.

${ }^{20} \mathrm{He}$ was supported, in vain, by Baer and Köppen against Sjögren, who backed Castren (who eventually won the scholarship of the Russian Academy of Sciences). (BALASSA 1952:172-180). Reguly plotted his map with a commission from the Russian Geographical Society (BoRBÉLY 1955:235-239).

${ }^{21}$ This is evidenced by Pápai's own statement: "It was beyond our hopes to find such considerate support from an allegedly hostile country in times declared to be laden with conflict. This thoughtful support made our journey possible at all, also largely facilitating it financially." (PÁPAI 1890:120); and by Munkácsi: "In view of the political developments of recent years, it is quite understandable that we did not look forward to our assignment without anxieties and that we were pleasantly surprised to find readiness and sympathy by the academic and official circles for our cause." (MuNKÁcSI 1889:212).

${ }^{22}$ On his privations during the journey in Udmurtia see Kozmács's witty account: 2012:76-126.

${ }^{23}$ On the acquisition and advantages of the letter of credence Munkácsi writes in detail and provides a translation of the entire letter (MunKÁCSI 1889:212-214). On Pápai's contacts in Russia (BalassA 1952:181-183), on his short trip to the Ural (PÁPAI 1888:620).

${ }^{24}$ They also reported on this in the warmest tones (BALASSA 1952:183-190; JANKÓ 1900:15-39; PÁPAY 1905:357-358; RUSVAY 2005) 
Along with the sympathy with which Russians embraced travelers from AustriaHungary, especially Hungarians, the infrastructure of the monarchy itself enabled its subjects to carry out expeditions and long research trips by granting them entrance to Russia and China via its network of embassies (BARÁTHOSI 1927:5; ZICHY 1905:224, 253). Simultaneously, subjects of the Dual Monarchy could make use of their aristocratic network (ZICHY 1905:224, 226). Researchers who lacked this aristocratic background could establish or use the existing relationship between Austro-Hungarian and Russian scientific institutions (BARÁTHOSI 1927:5-9). It was also useful for travelers to create private business contacts, especially in the peripheral regions (BARÁTHOSI 1927:11); although the embassies organized their own scientific expeditions to study these far-off regions (GUBÁNYI 1907:18), they lacked effective influence beyond the vicinity of the capitals where they were located (ZICHY 1905:253-254). Until the October Revolution, the Hungarian network in the peripheries led to one Hungarian businessman in Vladivostok (BARÁTHOSI 1927:11; GUBÁNYI 1908:3). In the beginning of the 1900s, a Hungarian hotel, The Austria, had the best restaurant in Nikolsk - the administrative center of the Ussuri region. Its guests could converse in four or five languages (GUBÁNYI 1907:71). These business hubs helped travelers from the Monarchy to purcase alimentation and gain information about local conditions.

The Austrian Lloyd, a shipping company, proved another valuable institution for travelers from the Austro-Hungarian Empire. The Lloyd practically held a monopoly for Austrian foreign postal services and had its own steamship ocean liners. Josef Troll used the Lloyd to send his collection of ethnographic objects to the Court Museum in Vienna. The items were placed on a small vessel to Batumi on the east coast of the Black Sea, which had been captured by the Russians in 1878 and where an Austrian honorary vice consulate, which functioned as an agency of the Lloyd, was founded in 1884. From there the objects were transported with a steamship belonging to the Austrian Lloyd to Trieste, the Austrian sea port on the Adriatic coast. Troll also returned home once with one of the company's liners (ÖFNER 2011:24, 60, 94-97, 119, 138).

\section{THE CULTURAL BACKGROUND OF TRAVELERS FROM THE DUAL MONARCHY}

As previously stated, those who traveled to the Asian peripheries of Russia from the monarchy left behind a huge corpus of written as well as visual records. In order to better understand their works and their perspective on non-European peoples, it is necessary to outline the socio-cultural background of the monarchy's subjects.

Knowledge concerning non-European, indigenous peoples did not exist independently of the time and socio-cultural micro context in which it was born and received, and which thereby shaped its form and meaning. The distinct view Hungarian travelers had on Siberia (or any other part of the world) may have stemmed from the social and cultural circumstances they were raised in and from the political establishment of the monarchy in which they had to find their place and upon which they sometimes reflected. This is much clearer and more evident in the first part of the $19^{\text {th }}$ century with the cultural movement of the Hungarian national awakening that attempted to create a distinct, scientific discourse in the Hungarian vernacular following the rather Protestant pattern of knowledge 
originating primarily in German universities (especially in Göttingen) ${ }^{25}$ It is not so clear, however, how this view came about in the second half of the $19^{\text {th }}$ century, especially around and after the Compromise (Ausgleich) of 1867. Earlier models of representation, and an explicit hostility towards the Habsburg/Catholic learning, continued to appear for some time. Even later, German (János Hunfalvy), British (Áron Vámbéry and Aurél Stein), and American (János Xántus) scholarly orientations could be detected. ${ }^{26}$

We do have a clearer picture, however, on the works which were present in the monarchy concerning non-European peoples and what perspective they transmitted on Oriental otherness. In Hungary, for instance, notions about the indigenous inhabitants of distant lands arrived via travelers' accounts, peregrinating students' knowledge gathered at foreign (primarily Western European) universities, and, no less importantly, translations and adaptations of foreign (mostly Western European) works. Among the latter, schoolbooks on geography and natural history, as well as travel accounts, constituted the most important channels carrying ethnological, and early anthropological notions. Between 1790 and 1840 a whole series of works originating in the centers of Western European culture were adapted in order to supplement Hungarian science. The same kind of textual and visual strategies of othering appeared in East-Central Europe, i.e. in AustriaHungary, as appeared in the representational conventions of the great Atlantic empires, Spain, France, and Great Britain; the physical and political lack of (considerable) colonies did not grant exemption or immunity from culturally biased representations ${ }^{27}$ This is especially evident and visible, as previously mentioned, in the first half of the $19^{\text {th }}$ century.

Ethnographic fieldworkers and other travelers from the period were also influenced by geographical and other kinds of school books (travelogues, works of natural history, even poetry and literature, etc..${ }^{28}$ Such works were present in schools, academic circles and also in the field, shaping their knowledge and impacting their imagination. It is thus important to know who referred to which work, in what context, and with what intention.

Aurél Stein admired and admittedly followed the travels of Marco Polo (1254-1324) and Alexander the Great (356-323 BC), frequently commenting upon them in his travel narrative. He also carried with him a contemporary French edition of Xuanzang's Chinese geography (STEIN 1986, 2010; STEWART 2014). Vámbéry's youthful fantasies were admittedly fueled by an idealized image of the East: by "travelogues and lighter histories" and also by the art of Byron, Voltaire, Garcilaso de la Vega, and Esaias Tegnér (1782-1846) (VÁMBÉRY 1966:6-9; 2014). Zichy referred to Heinrich Julius Klaproth (1783-1835) and Adolf Bastian (1826-1905) as his principal authorities (ZICHY 1897). Troll read and used Francis Galton's The Art of Travel (GaLton 1872), Georg von

${ }^{25}$ On the Hungarian national awakening see KonTLER 1999:222-246. On the Protestant patterns of knowledge and the role of the University of Göttingen in Hungary GURKA 2003; 2010; KONTLER 2013; Sz. KRISTÓF 2011, 2013, 2017; VERMEULEN 2008

${ }^{26}$ The geography of Alexander von Humboldt (1769-1859) is a considerable influence seen in Hungarian (Protestant) scholarship, ethnology/anthropology included, throughout the $19^{\text {th }}$ century (Hunfalvy 1995; Sz. KRISTÓF 2014a, 2017).

${ }^{27}$ For individual analyses of these tranlations see Sz. KRISTóf 2011, 2013, 2014 b, 2017.

${ }^{28}$ The text that follows on schoolbooks and early anthropological stereotypes is based on an unpublished paper presented by Ildikó Sz. Kristóf at the workshop, "Representations of Indigenous Peoples of the Asian Peripheries of the Russian Empire (Northern and Inner Asia) in the Legacies of Travelers from Austro-Hungary", held at the Department of Social and Cultural Anthropology of the University of Vienna, 22-24 February 2017. 
Neumayer's book on traveling (NeumaYer 1875), and even Baedeker's travel guides (ÖFNER 2011:53-54). Also, Jankó was fascinated by "the [Finnish] national culture emerging out of the Kalevala", and chatted eagerly about anyone who had ever dealt with it (JANKó 1993). These examples could and should be multiplied.

How exactly did these works exert their influence on the first (and perhaps, second) generation of Hungarian travelers, fieldworkers, scholars and others? How did the representations presented in such works develop and change during the second half of the $19^{\text {th }}$ century? What happened to these stereotypes as fieldworkers met indigenous peoples in Siberia? Were they clung to (as Jankó did to some extent), or were they overcome? And, last but not least, how did indigenous peoples react? The answers to these questions would lead to a better understanding of to what extent the Austro-Hungarian representation of Siberia, Central- and Inner-Asia was a version of "Orientalism" (SAID 1978), or/and a sort of "cultural colonialism" (THOMAs 1994).

Aside from the influence of common scientific paradigms, other factors may have influenced the work of travelers from the monarchy. We argue that the common spaces for ethnological discourse in the monarchy enhanced communication between Austrian, Czech, and Hungarian researchers. In our preliminary research we spotted only a few occurrences of effective cooperation between researchers of different ethnic affiliation, but more thorough research may shed light on how Austrian, Czech, and Hungarian ethnological researchers have done so, or at least how they influenced each other.

In fact, a number of research expeditions were carried out with researchers of various ethnic backgrounds. For example, a k.u.k. merchant expedition to India, China, Siam and Japan was organized in 1868 involving, among others, the Austrian explorer Karl von Scherzer and János Xántus, a Hungarian scientist (or polymath). Expeditions organized by Széchenyi and Almásy also involved Austrian researchers and travelers. However, no print evidence of financial or material support or cooperation between the two national organizations, the Anthropological Society in Vienna (Anthropologische Gesellschaft in Wien) and the Hungarian Ethnographic Society (Magyar Néprajzi Társaság), has been found so far. The journals, Mitteilungen der Anthropologischen Gesellschaft Wien (published in Vienna from 1870 onwards) and Ethnographia (published in Budapest from 1890 onwards), tend to report on the expeditions and scientific results of researchers in other countries, without emphasizing their joint nature. The journal of the Hungarian Ethnographic Museum (Néprajzi Értesitö), founded in 1900, had more references to the content of the Mitteilungen than the Ethnographia.

The most active and prolific members of the Hungarian Ethnographic Society and/or of the editorial team of the Ethnographia, however, were also authors in the Mitteilungen, such as Antal Herrmann (who also edited a German-language ethnological journal in Hungary between 1887 and 1907), Aurél Török and Ottó Herman. ${ }^{29}$ In addition, when an acknowledged Hungarian researcher or writer died, the obituary was published in the Mitteilungen, as was the case with Pál Hunfalvy. There are some examples where it is difficult, due to the melting pot effect of the monarchy, to track the author's national identity. For instance, Josef Szombathy, widely known for his role in finding the Venus

\footnotetext{
${ }^{29}$ It is no surprise that only these researchers (interested in physical anthropology and archeology) published in the Vienna-based journal, physical anthropology had a more central position than ethnology in Austrian ethnographic scholarship in the late $19^{\text {th }}$ century (GINGRICH 2016).
} 
of Willendorf, was an Austrian of Hungarian ancestry on his father's side (HEINRICH 2003). He worked as chief editor of the Mitteilungen in the 1880s.

For Czechs, the case was a bit different. Before establishing their own institution, Czech ethnographers tended to present their findings in the Mitteilungen der Anthropologischen Gesellschaft Wien, where the paleontologist and archaeologist, Jan Nepomuk Wodrich, was a member of the editorial team. The founding of the Czech and Slovak Ethnographic Society (Československá národopisná společnost) in 1893 did not mark the end of Czechs publishing in the Austrian journal. The fact that Národopisný sborník českoslovanský, the Czechs' own ethnographic journal, started only in 1906 might be the reason for, and the consequence of, the relatively close bond between Czech and Austrian ethnologists, which differed from their Hungarian counterparts' constant desire for independence.

\section{CONCLUSION AND OUTLOOK}

The goal of our joint research endeavor going forward is to provide a number of comprehensive case studies for the purpose of comparison. We aim to closely examine the personal backgrounds of specific travelers, the peculiarities of their travels and the impact they had on them, and, if detectable, on the indigenous people they visited, their ethnographic outcomes and value, the character of their accounts, as well as the impact they had on society in general and on the development of the discipline of ethnology/ anthropology in particular.

Through this comparative analysis, for which this article serves as a launch pad, we aim to contribute to three ongoing anthropological and historical discourses. First, we plan to scrutinize the much-debated notion of orientalism. We argue that it is necessary to examine local phenotypes of the creation of Oriental otherness in $19^{\text {th }}$-century Europe rather than an overarching, uniform idea of orientalism - to separately examine German (MARCHAND 2010), French (Hosford - WoJTKOWSKi 2010), Austro-Hungarian (LemON 2011), and even Hungarian (STAUD 1999) orientalism as instructive notions. We focus on the Austro-Hungarian and Hungarian orientalisms because they seem remarkably underexamined, and all of the above presented peculiar socio-cultural preconditions and trajectories, as well as individual endeavors and achievements that seem highly conspicuous of being able to reveal distinct forms of constructing (Oriental) otherness, which have so far not been described and deconstructed.

Second, we argue that the corpus of ethnographic accounts written by travelers from the monarchy on Russia and the neighboring regions in the $19^{\text {th }}$ century are the direct successors of expeditions in the $18^{\text {th }}$ century that were led by natural scientists in Siberia, whose work brought about the emergence of systematic ethnographic research (SCHWEITZER 2013) and the type of travel carried out by "reisende[n] Gelehrten" (SLEZKINE 1994). The ever-growing corpus of German works on the oriental subordinates of the Russian state did significantly contribute to the development and shaping of ethnology (Völkerkunde) in Europe (VERMEULEN 2015), including in the Austrian Empire where it had an enormous impact on Hungarian, Austrian and Czech intellectuals (SÁRKÁNY 2012).

The example of the monarchy will contribute to a more detailed picture of how new ideas (like Völkerkunde) that were born in the centers of German enlightenment 
impregnated the intellectual life of the more peripheral regions of Europe. At the same time, we argue that Völkerkunde/egyetemes néprajz/etnologie, and Volkskunde/néprajz/ národopis developed within national research traditions rather than in the frames of a monolithic European intellectual project (cf ScHWEITZER 2001). Our question is whether or not the Austro-Hungarian Dual Monarchy provided a meaningful frame to bridge national research traditions. Thus, we may contribute to a better understanding of the spread and popularity of ethnographic scholarship in Europe.

Third, in examining the common features of the endeavors of various Austrian, Czech, Hungarian, and Polish travelers from the monarchy, and the heterogeneous corpus of accounts left behind, we are looking for traces of a common approach to non-European peoples. We are interested in how and to what extent travelers from the monarchy were endowed with a distinct cultural (Thomas 1994) or soft (PRUTsch 2003:36) colonial attitude towards Asian otherness.

In order to achieve these goals we revisit known accounts of those who traveled from the monarchy to the peripheries of the Russian Empire, and search for new ones, both in public and private archives, to analyze and contextualize them in the sociocultural environment and the spheres of scholarship that existed in the monarchy and beyond. In doing so we journey to new ground, like the protagonists of our research, to expand our ethnographic knowledge as well as the history and underlying driving forces of our discipline.

\section{REFERENCES CITED}

Almásy, György

1903 Vándor-úton Azsia szivébe [Travel into the Heart of Asia]. Budapest: Temészettudományi Társulat.

ANDERSON, Benedict

2006 Képzelt közösségek. Gondolatok a nacionalizmus eredetérö és elterjedéséről [Imagined communities. Reflections on the origin and spread of nationalism]. Budapest: L'Harmattan - Atelier.

ANDREEVA, Elena

2007 Russia and Iran in the great game: Travelogues and Orientalism. London: Routledge.

Ash, Mitchell G. - Surman, Jan

2012 The Nationalization of Scientific Knowledge in Nineteenth-Century Central Europe: An Introduction. In AsH, Mitchell G. - Surman, Jan (eds) The Nationalization of Scientific Knowledge in the Habsburg Empire, 1848-1918, 1-29. Basingstoke: Palgrave - Macmillan.

Augustin, Reinhard

1934 Taiga: abenteuerliche Erlebnisse in den Urwäldern des fernen Ostens. Leipzig: Assmus.

1936 Durch Mandschukuo: abenteuerliche Erlebnisse im Lande des Opiums. Reichenberg: Kraus.

1939 Der arische Führertypus als Baumeister des Lebens. Bad Furth b. München: Deutscher Hort-Verlag. 
BALASSA, Iván

1952 A Néprajzi Múzeum kapcsolatai az orosz néprajztudománnyal [Relations of the Museum of Ethnography with Russian ethnography]. Ethnographia 63:171-201.

1954 Reguly Antal néprajzi gyüjteménye (1840-45) [Antal Reguly’s ethnographic collection]. Néprajzi Értesítö 56:47-64.

BARÁTHOSI BALOG, Benedek

1927 Bolyongások mandsur népek között [Rambling among Manchu peoples]. Baráthosi turáni könyvei II. Budapest: Author.

BASSIN, Mark

1991 Russia between Europe and Asia: The Ideological Construction of Geographical Space. Slavic Review 50:1-17.

BĚLKA, Luboš

2009 Burjatské buddhistické chrámy první čtvrtiny 20. století a vizuální dějiny [Buryat Buddhist Shrines in 1920s and the Visual Studies]. In SLOBodNík, Martin (ed) Našinec v Oriente. Cestovatelia zo Slovenska a Čiech v Ázii a Afrike (19. - I. pol. 20. storočia), 199-210. Bratislava: Univerzita Komenského.

2011 Acagatský klášter: Vizuální dějiny buddhismu [Atsagat Monastery: Visual History of Buddhism]. Nový Orient 66(1):42-48.

BOKOR, Ervin

1919 Menekülés a szibériai fogságból Japánon és Anglián keresztül. (Két magyar tiszt viszontagságai) [Escape from Siberian ceptivity through Japan and England]. Budapest: Franklin Társulat.

BorbÉLY, Andor

1955 Reguly Antal térképének szerepe az Észak-Ural megismerésében [The role of Antal Reguly's map in the exploration of the Northern Ural]. Földrajzi Közlemények 79(3):231-241.

BREULLY, John

2013 Nationalism and National Unification in the Nineteenth-Century Europe. In Breully, John (ed) The Oxford Handbook of the History of Nationalism, 149174. Oxford: Oxford University Press.

BRUNNER, Otto

1962 Staat und Gesellschaft im vormärzlichen Österreich im Spiegel von I. Bedteils Geschichte der österreichischen Staatsverwaltung 1740-1848. In CoNZE, Werner - SchiEdER, Theodor (eds) Staat und Gesellschaft in deutschen Vormärz, 51-75. Stuttgart: Ernst Klett Vverlag.

Búr, Gábor

2011 A Habsburg-birodalom gyarmatpolitikája. [Colonial Politics of the Habsburg Empire] In BúR, Gábor: Afrika-történeti tanulmányok. Budapest: Mundus Novus Könyvek Kft.

Burbank, Jane - von Hagen, Mark - Remnev, Anatolyi (eds)

2007 Russian Empire: Space, People, Power, 1700-1930. Bloomington: Indiana University Press. 
Bureau der K. K. Statistischen Zentralkomission

1912 Die Summarische Ergebnisse der Volkszählung. Die Ergebnisse der Volkszählung vom 31. Dezember 1910 in den im Reichsrate vertretenen Königreichen und Ländern. Heft 1. Wien: Kaiserlich- Königliche Hof- und Staatdruckerei - Karl Gerolds Sohn.

Chaudhury, Sushil (ed)

1999 Merchants, Companies and Trade: Europe and Asia in the Early Modern Era. Cambridge: Cambridge University Press.

CHOLnoky, Jenő

1900 A sárkányok országából. Életképek és utirajzok Khinából [From the Country of Dragons. Travel Notes from China]. Veszprém: Köves és Boros könyvkiadóhivatala.

Clifford, JAMES

1997 Spatial Practices: Fieldwork, Travel, and the Disciplining of Anthropology. In Gupta, Akhil-Ferguson, James (eds) Anthropological Locations. Boundaries and Grounds of a Field Science, 185-222. Berkeley: The University of California Press.

CulPIN, Christopher - HeNIG, Ruth B.

1997 Modern Europe: 1870 - 1945. Harlow: Longman.

DeÁk, Ágnes

2000 Nemzeti egyenjogúsitás. Kormányzati nemzetiségpolitika Magyarországon, 1849-1860 [National emancipation. The government's nationality policy in Hungary, 1849-1860]. Budapest: Osiris.

DEMETER, Gábor

2007 Kisállami törekvések és nagyhatalmi érdekek a Balkán-háborúk idején (1912_ 1913) [Aspiration of small states and the motives of great powers during the Balkan Wars]. Budapest: Hungarovox Kiadó.

DiósZEGI, István

2001 Az Osztrák-Magyar Monarchia külpolitikája 1867-1918 [The foreign policy of the Austro-Hungarian Monarchy 1867-1918]. Budapest: Vince Kiadó.

DONIA ROBERT, J.

2008 The Proximate Colony. Bosnia-Herzegovina under Austro-Hungarian Rule. In Ruthner, Clemens - Reynolds, Diana - ReBer, Ursula - Detrez, Raymond (eds) WechselWirkungen. The Political, Social and Cultural Impact of the Austro-Hungarian Occupation of Bosnia-Herzegovina (1878-1918), 67-82. New York: Peter Lang.

DózSA F., Katalin

1996 A rendi nemzettudat szimbóluma, a díszmagyar [Symbol of the feudal national consciousness: the gala outfit]. In HofER, Tamás (ed) Magyarok kelet és nyugat között, 155-166. Budapest: Néprajzi Múzeum - Balassi.

Forbáth, László (Geleta József tanulmányai alapján)

1934 A megújhodott Mongólia [The New Mongolia]. Magyar Földrajzi Társaság sorozata. Budapest: Franklin Társulat.

Fuchs, Brigitte

2003 "Rasse”, "Volk”, Geschlecht: anthropologische Diskurse in Österreich 18501960. Frankfurt: Campus. 
FUTAKY, István

2007 Göttinga. A göttingeni Georg-August-Egyetem magyarországi és erdélyi kapcsolatai a felvilágosodás idején és a reformkor kezdetén [Göttingen. Relations between the Georg August University of Göttingen and Transylvania during the era of enlightenment and the Hungarian reform era]. Budapest: ELTE

GaLton, Francis

1872 The art of travel; or, shifts and contrivances available in wild countries. London: Murray.

Gatrell, Peter

2005 Prisoners of War on the Eastern Front during World War I. Kritika: Explorations in Russian and Eurasian History 6(3):557-566.

GELLNER, Ernest

2009 A nemzetek és a nacionalizmus [Nations and nationalism]. Budapest: Napvilág.

GINGRICH, Andre

2016 Science, Race, and Empire: Ethnography in Vienna before 1918. East Central Europe 43:41-63.

GombÁr, Csaba -Kende, Péter-Lengyel, László -Romsics, Ignác-SzILÁgyi, Ákos

2002 Nem élhetek birodalom nélkül [I cannot live without an empire]. Budapest: Helikon Kiadó.

GUBÁNYI, Károly

1907 Öt év Mandzsúországban [Five Years in Manchuria]. Magyar Földrajzi Társaság sorozata. Budapest: Lampel Róbert.

1908 Vladivosztok 1907-ben [Vladivostok in 1907]. Földrajzi Közlemények 36(1):1-6.

GuRKa, Dezső

2003 Reflexiók és iniciatívák. Az Európán kívüli világ (re)prezentációja a göttingai egyetemen [Reflections and initiatives. Representations of Non- European worlds at the Unviersity of Göttingen]. Magyar Filozófiai Szemle 47(3):341357.

Gurka, Dezső (ed)

2010 Göttingen dimenziói. A göttingeni egyetem szerepe a szaktudományok kialakulásában [The dimensions of Göttingen. The role of the University of Göttingen in the formation of sciences]. Budapest: Gondolat Kiadó.

GYÖRFFY, György

1993 Krónikáink és a magyar östörténet: régi kérdések - új válaszok. Budapest: Balassi Kiadó.

HAJDÚ, Péter

1953 Reguly, a nyelvész [Reguly the linguist]. Magyar Nyelvör 77:327-330.

HASLINGER, Peter

2012 How to run a Multilingual Society. Statehood, Administration and Regional Dynamics in Austria-Hungary, 1867-1914. In Augusteisn, Joost - Storm, Eric (eds) Region and State in Nineteenth-Century Europe. Nation-Building,

HASLIP, Joan Regional Identities and Separatism, 111-128. Basingstoke: Springer.

1971 Imperial Adventurer-Emperor Maximilian of Mexico. London: Sphere Books. 
HeINRICH, Angelika

2003 Josef Szombathy (1853-1943). Mitteilungen der Anthropologischen Gesellschaft in Wien 133:1-45.

HoFer, Tamás

1989 Paraszti hagyományból nemzeti szimbólumok - adalékok a magyar nemzeti müveltség történetéhez az utolsó száz évben [National Symbols from the Peasant Tradition - Addenda to the History of the Hungarian Nation in the Past One Hundred Years]. Janus 6(1):59-74.

2009 A nemzeti történelem rávetítése a népmüvészetre [The Projection of National History onto Folk Art]. In HofER, Tamás (ed) Antropológia és/vagy néprajz. Tanulmányok két kutatási terület vitatott határvidékéröl, 145-166. Budapest: MTA NKI - PTE BTK Néprajz - Kulturális Antropológia Tanszék L'Harmattan.

HonTi, László (ed)

2010 A nyelvrokonságról. Az török, sumer és egyéb áfium ellen való orvosság [On Language Relations. An Antidote to the Turkish, Sumerian and Other Poison]. Budapest: Tinta.

Hosford, Desmond - WojtKowski, Chong J. (eds)

2010 French Orientalism: Culture, Politics, and the Imagined Other. Newcastle: Cambridge Scholars.

Hulme, Peter - Youngs, Tim (eds)

2002 The Cambridge companion to travel writing. Cambridge: Cambridge University Press.

Hunfalvy, János

1995 Egyetemes néprajz (Ethnographia). Dr. Hunfalvy János egyetemi nyilvános rendes tanár elöadásai után szerkeszté Rácz Géza úr [General Ethnography. University Lectures of János Hunfalvy Edited by Jenő Rácz]. Budapest: MTA Néprajzi Kutatóintézet.

HuszKA, József

1900 Magyarische Ornametnik. Budapest: Pátria.

IsTVÁN, Erzsébet

1996 Keleti örökség, népmüvészet, historizmus: Zsolnay Vilmos és Badár Balázs kísérletei [Eastern legacy, folk art, historism: the attempts of Vilmos Zsolnay and Balázs Badár]. In Hofer, Tamás (ed) Magyarok kelet és nyugat között, 191-208. Budapest: Néprajzi Múzeum - Balassi.

JAKL, Tomáš

2006 Sbírka fotografií československých legií ve Vojenském historickém ústavu [The Photographic Collection of the Czechoslovak Legion in the Institution of Military History]. Historická fotografie 6(1):29-45.

JANKÓ, János

1900a A magyar halászat eredete - Herkunft der magyarischen Fischerei. Budapest - Leipzig: Hornyánszky V. - Karl W. Hiersemann.

1900b A néprajz Finnországban [Ethnography in Finland]. Néprajzi Értesitő 1:1-13.

1993 Finnországi jegyzetek [Notes from Finland]. Budapest: Néprajzi Múzeum.

2000 Utazás Osztjákföldre [A Journey to Ostyak Land]. Budapest: Néprajzi Múzeum. 
JÁszI, Oszkár

1929 The dissolution of the Habsburg Monarchy. Chicago: University of Chicago Press.

JISL, Lumír

1963 Hans Leder, ein vergessener Reisender. Abhandlungen und Berichte des Staatlichen Museums für Völkerkunde Dresden 22:25-56.

K. D.

1821 Emlékirás a' Nemes Magyar Nemzethez, melly magában egy Javallatot foglal, a' Magyarok' régi lakhelyeinek,'s a' még ottan lakó régi Magyarok' maradványainak felkeresésére éjszak napnyugoti Asiába a' szárazon küldendő Expeditzióról [Proposal to the Hungarian Nation for Sending Terrestrial Expeditions to the Remains of Hungarians Living in the Orient]. Tudományos gyüjtemény 5(5):67-88.

KanN, Robert A.

1950 The Multinational Empire: Nationalism and National Reform in the Habsburg Monarchy, 1848-1918. New York: Columbia University Press.

KÁlmán, Béla

1981 Munkácsi Bernát [Bernát Munkácsi]. Budapest: Akadémiai Kiadó Kiss, Attila

2015 Magyar Kelet-politika a rokonság jegyében - az östörténet, mint társadalomés gazdaságpolitikai tényezö 100 éve és ma [The Hungarian East-Policy in the Frames of Relatives - Ancient History as Social and Economic Factor 100 Years Ago and Today]. Budapest: Pallas Athéné Domus Animae Alapítvány.

KodOLÁNYI, János ifj.

1959a Reguly Antal [Antal Reguly]. Ethnographia 70:359-367.

1959b Reguly Antal néprajzi tárgy-gyüjteménye [Antal Reguly’s Collection of Ethnographic Objects]. Néprajzi Értesítö 61:283-302.

KoHARA, Toshihiro - WilHelm Gábor

1999 Baráthosi Collection Catalogue. Sapporo-Budapest: Hokkaido Ainu Culture Reserach Center - Museum of Ethnography.

KONTLER, László

1999 Millenium in Central Europe. A History of Hungary. Budapest: Atlantisz Publishing House.

2013 Distances Celestial and Terrestrial. Maximilian Hell's Arctic Expedition, 1768-1769: Contexts and Responses. In Holenstein, André - Steinke, Hubert - STUBer, Martin (eds) The Practice of Knowedge and the Figure of the Savant in the Eighteenth Century, 721-750. Leiden: Brill.

KOŘENSKÝ, Josef

1910 Sibiři např́čč [Across Siberia]. Praha: J. Otto.

1920 Asie: kulturní obrázky z asijského severu a východu; Zakaspicko. Mongolsko. Tibet. Ćna. Japonsko. Korea [Asia: Cultural Pictures from North and East Asia, Transbaikalia, Mongolia, Tibet, China, Japan]. Praha: A. Storch a syn.

Korompay, Bertalan

1971 Reguly és hagyatéka [Reguly and his Legacy]. Nyelvtudományi Közlemények $73: 387-407$. 
KozMÁcs, István

2010 Munkácsi Bernát és a magyar nyelvészeti terepmunka kezdetei [Bernát Munkácsi and the Beginnings of Hungarian Linguistic Fieldwork]. Nyelvtudományi Közlemények 107:258-275.

2012 Munkácsi Bernát élete. „Aki adott szavától elválik, saját lelkétől válik el” [The Life of Bernát Munkácsi. "One who Departs from his Promise Departs from his Soul"]. Pozsony: AB-ART Kiadó.

Kuehn, Julia - Smethurst, Paul (eds)

2009 Travel Writing, Form, and Empire. The Poetics and Politics of Mobility. London: Routledge.

LANG, Maria-Katharina

2010 Mongolische Ethnographica in Wien: die Sammlung Hans Leder im Museum für Völkerkunde Wien. Wien: Verlag der Österreichischen Akademie der Wissenschaften.

LEDER, Hans

1908 Vom Changai nach dem Altai. Deutsche Rundschau für Geographie und Statistik 1:7-23, 2:69-79.

1909 Das geheimnisvolle Tibet: Reisefrüchte aus dem geistlichen Reiche des DalaiLama. Leipzig: Grieben.

LEIDINGER, Hannes - MoRITZ, Verena

1997 Österreich-Ungarn und die Heimkehrer aus russische Kriegsgefangenschaft im Jahr 1918. Österreich in Geschichte und Literatur 6:385-403.

LEMON, Robert

2011 Imperial Messages: Orientalism as Self-critique in the Habsburg Fin de Siècle. Rochester: Camden House.

MARCHAND, Suzanne L.

2010 German Orientalism in the Age of Empire: Religion, Race, and Scholarship. Cambrdge: Cambridge University Press.

MARKovits, Andrei S.

1982 Introduction: Empire and Province. In MARkovits, Andrei S. - SysYN, Frank E. (eds) Nationbuilding and the Politics of Nationalism: Essays on Austrian Galicia, 1-22. Cambridge: Harvard University Press.

Mathew, Kuzhippalli Skaria (ed)

1995 Mariners, Merchants and Oceans: Studies in Maritime History. New Delhi: Manohar.

MeINECKE, Friedrich

1908 Weltbürgertum und Nationalstaat: Studien zur Genesis des deutschen Nationalstaates. München: Oldenburg.

MiskolCZY, Ambrus

2012 A ,hungarus-tudat” a polgári-nemzeti átalakulás sodrában [The "Hungarus” Awareness in the Surge of Bourgeois-National Transformation]. Magyar Kisebbség 17(3-4):163-204.

Montgomery, Robert Lynn - ChIEn, Jennifer

2006 Register to the Papers of Aleš Hrdlička. Washigton D. C.: Smithsonian Institution. 
M. B. (MunKÁCSI, Bernát)

1897 Zichy Jenő gróf harmadik ázsiai útjáról [On Jenő Zichy’s Third Journey to Asia]. Ethnographia 8:238-239.

MunKáCSI, Bernát

1882 A magyar összehasonlító nyelvtudomány első virágzásának kora [The First Golden Era of Hungarian Comparative Linguistics] Magyar Nyelvör 11:385-393.

1887a Votják népköltészeti hagyományok [Traditional Votyak Folk Poetry]. Budapest: Magyar Tudományos Akadémia.

1887b Csuvas nyelvészeti jegyzetek [Notes on the Chuvash Language]. Nyelvtudományi Közlemények 21:1-44.

1889 Nyelvészeti tanulmányutam a vogulok földjén [My Linguistic Research Trip among the Voguls]. Budapesti Szemle 155:206-238, 156:382-408.

2008 Megvalósult gyermekálom (Munkácsi Bernát udmurtföldi naplója) [A Child’s Dream Realized. Bernát Munkácsi’s Diary on Udmurtia]. Közreadja: KozMÁcs István. Pozsony: AB-Art.

MUNKÁCSI, Noémi

1943 Egy nagy magyar nyelvész. Munkácsi Bernát élete [A Great Hungarian Linguist. The Life of Bernát Munkácsi]. Budapest: Izraelita Magyar Irodalmi Társulat.

NACHTIGAL, Reinhard

1996 Kriegsgefangene der Habsburgermonarchie in Russland. Österreich in Geschichte und Literatur 6:385-403.

NAGY, Mariann - KaTUS, László

2010 A Magyar Korona országainak nemzetiségei a 18-19. században [Nationalities of the Lands of the Hungarian Crown in the $18-19^{\text {th }}$ Centuries]. http://www. arkadia.pte.hu/tortenelem/cikkek/magyar_korona_orsz_nemzetisegei_1819sz (accessed July 12, 2017.)

NAGY, Zoltán

2012 Karoi Papai: vengerskii issledovatel' na territorii Tomskoi oblasti [Károly Pápai a Hungarian Researcher at the Tomsk Disctrict]. In TuchKov, Aleksandr Gennadevich (ed) Trudy Tomskogo oblastnogo kraevedcheskogo muzeia im. M.B. Shatilova: Materialy polevykh issledovanii 17:187-215. Tomsk: Izdatel'stvo Veter.

NeUmaYer, Georg von (ed)

1875 Anleitung zu wissenschaftlichen Beobachtungen auf Reisen. Mit besonderer Rücksicht auf die Bedürfnisse der Kaiserlichen Marine. Berlin: Verlag von Robert Oppenheim.

OrIÁN, Edmund (ed)

2014 Československá legie v Rusku 1914-1920 [The Czechoslovak Legion in Ormos, István Russia 1914-1920]. Praha: Naše vojsko.

2012 Adalékok Pröhle Vilmos alakjához [Fragments to the Figure of Vilmos Pröhle]. Keletkutatás 1:33-65.

Отснет 1891

1892 Otchet o deyatel'nosti Vostochno-Sibirskogo otdela IRGO za $1891 \mathrm{~g}$ [Report on the Activity of the East-Siberian Department of the Russian Geographic Society from 1891]. Irkutsk: IRGO. 
ОTCHET 1892

1894 Otchet o deyatel'nosti Vostochno-Sibirskogo otdela IRGO za $1892 \mathrm{~g} g$ [Report on the Activity of the East-Siberian Department of the Russian Geographic Society from 1892]. Irkutsk: IRGO.

ÖFNER, Elisabeth

2011 Josef Troll - seine Reise nach Russisch-Turkestan 1888/89 und seine Widerspiegelung im schriftlichen Nachlass und den Sammlungen des Museums fur Völkerkunde in Wien. Diplomarbeit, Wien: Universität Wien.

PAIKERT, Alajos

1914 A Turáni Társaság eddigi és jövendő müködése [Activity of the Turan Society So Far and its Future]. Budapest: Fritz Ármin.

PÁPAI, Károly

1888 Dr. Pápai Károlynak előzetes jelentése Nyugot-Szibériába tett utazásáról [Dr. Károly Pápai's Preliminary Report about his Journey to Western Siberia]. Földrajzi Közlemények 16:619-624.

1889 Jelentés Dr. Pápai Károlynak Éjszaknyugati Szibériában tett utazásáról [Report on Károly Pápai's Journey in Northwestern Siberia]. Földrajzi Közlemények 17:422-426.

1890 A vogulok és osztjákoknál. Pápai Károly jelentése anthropológiai és néprajzi tanulmányútjáról [Among the Voguls and Ostyaks. Károly Pápai’s Report about his Anthropological and Ethnographic Study Trip]. Ethnographia $1: 117-130$.

1891 Unter Wogulen und Ostjaken. Etnologische Mitteilungen aus Ungarn. 2:65-67. PÁPAY, József

1905 Osztják népköltési gyüjtemény. Az osztják nép hitvilágára vonatkozó hősi énekek, istenidézö igék és medveénekek. Reguly Antal hagyatéka és saját gyüjtése alapján közzéteszi Pápay József [Ostyak Folklore Collection. Heroic Songs, Invocations and Bear Songs Related to the Beliefs of the Ostyak People. Published on the Basis of Antal Reguly's Legacy and his Own Collection by József Pápay]. Budapest - Berlin: Hornyánszky - Hiersemann.

1906 Az osztjákok földjén [In the Land of the Ostyaks]. Földrajzi Közlemények 34:77-96, 172-185.

Phillips, Kim M.

2014 Before Orientalism. Asian Peoples and Cultures in European Travel Writing, 1245-1510. Philadelphia: University of Pennsylvania Press.

PISTOR, Erich

1905 Durch Sibirien nach der Südsee. Wirtschaftliche und unwirtschaftliche Reisestudien aus den Jahren 1901 und 1902. Wien-Leipzig: K. u. K. Hof- und Universitätsbuchhändler.

Pollitzer, Robert

1954 Plague. Geneva: World Health Organization.

1959 Cholera. With a Chapter on World Incidence. Geneva: World Health Organization.

1966 Plague and Plague Control in the Soviet Union. New York: Institute of Contemporary Russian Studies, Fordham University. 
1967 History and Incidence of Tularemia in the Soviet Union: A Review. New York: Institute of Contemporary Russian Studies, Fordham University.

PRATT, Mary Louise

1992 Imperial Eyes: Studies in Travel Writing and Transculturation. London: Routledge.

PRUTSCH, Ursula

2003 Habsburg postcolonial. In Feichtinger, Johannes - PRUTSCH, UrsulaCsÁKy, Moritz (eds) Habsburg postcolonial. Machtstrukturen und kollektives Gedächtnis, 33-43. Innsbruck: Studien Verlag.

PuszTAY, János

1977 Az ugor-török háború után [After the Ugric vs Turkic War]. Budapest: Magvetö.

1985 A hun mondától a finnugor rokonságig [From the Hunnish Myth to the FinnoUgrian Kinship]. In SzOMватHY, Viktor (ed) Az őshazától a Kárpátokig, 2771. Budapest: Panoráma.

RACHAMIMOV, Alon

2002 POWs and the Great War: Captivity on the Eastern Front. Oxford-New York: Berg.

RANDA, Alexander

1966 Österreich in Übersee. Wien: Herold.

RÁSONYI, László

1962 A magyar keletkutatás orosz kapcsolatai [Russian Contacts of Hungarian Oriental Studies]. A Magyar Tudományos Akadémia Könyvtárának Közleményei 26. Budapest: MTA Könyvtára.

Ratmanov, Pavel - Zhang, Fengmin

2015 Iz istorii rossiisko-kitaiskogo medetsinskogo sotrudnichestva: doctor U Lyande i protivochumnaya ekspeditsiya $\mathrm{v}$ Zabaikal'e [From the History of Russian-Chinese Collaborations in Medicine]. Dal'nevostochnyi meditsinskii zhurnal 4:102-107.

RIEDL-Dorn, Christa

2014 Botaniker - Pflanzenjäger - Intriganten. Die Rolle der Pflanzenkunde bei der Weltumsegelung der Fregatte „Novara” (1857-1859). In KäsTNER, Ingrid KIEFER, Jürgen - KIEHN, Michael - SEIDL, Johannes (eds) Erkunden, Sammeln, Notieren und Vermitteln - Wissenschaft im Gepäck von Handelsleuten, Diplomaten und Missionaren, 373-394. Aachen: Shaker Verlag.

Romanov, Nit S.

1993 Letopis'goroda Irkutska za 1881-1901 gody. Irkutsk: (n.p.)

Romsics, Ignác

2002 A magyar birodalmi gondolat [Hungarian Imperial Aspirations]. In GomBÁR, Csaba - Kende, Péter - Lengyel, László -Romsics, Ignác - SzILÁGYi, Ákos (eds) Nem élhetek birodalom nélkül, 41-81. Budapest: Helikon Kiadó.

RóNA-TAS, András

1978 A nyelvrokonság [On Linguistic Affinity]. Budapest: Gondolat.

SAHADEO, Jeff

2015 Home and Away. Why the Asian Periphery Matters in Russian History. Kritika: Explorations in Russian and Eurasian History 16(2):375-388. 
SAID, Edward W.

1978 Orientalism. New York: Pantheon Books, Random House Inc.

SANZHEYEV, G. D.

1980 Taylgan buryatskikh kuznetsov [Sacrificial Ritual of Buryat Smiths]. In BAzOYEVA K. D. (ed) Byt buryat v nastoyashchem i proshlom, 100-120. UlanUde: BFION AN SSSR

SÁRKÁNY, Mihály

2012 Etnográfia, etnológia és az antropológiai perspektíva - fogalmak egy tudomány születésekor [Ethnography, Ethnology and the Anthroplogical Perspective - Concepts at the Birth of a Discipline]. In TóTH, Arnold (ed) Néprajz - muzeológia: Tanulmányok a múzeumi tudományok köréböl a 60 éves Viga Gyula tiszteletére, 11-21. Miskolc: Borsod-Abaúj-Zemplén Megyei Múzeumi Igazgatóság - Miskolci Egyetem BTK Történettudományi Intézet.

SAUER, Walter (ed)

2002 K. u. k. kolonial Habsburgermonarchie und europäische Herrschaft in Afrika. Köln - Wien - Weimar: Böhlau.

SAUNDERS, Graham

2013 A History of Brunei. London: Routledge.

SCHEFBECK, Günther

2014 Wissenschaftliche Forschungen der k. (u.) k. Kriegsmarine. In KäsTNER, Ingrid - KIEFER, Jürgen-KIEHN, Michael-SEIDL, Johannes (eds) Erkunden, Sammeln, Notieren und Vermitteln - Wissenschaft im Gepäck von Handelsleuten, Diplomaten und Missionaren, 341-372. Aachen: Shaker Verlag.

SCHRADDER, Abby M.

2007 Unruly Felons and Civilizing Wives: Cultivating Marriage in the Siberian Exile System, 1822-1860. Slavic Review 66:230-256.

SCHWEITZER, Peter

2001 Siberia and Anthropology: National Traditions and Transnational Moments in the History of Research. Habilitationsschrift. Vienna: University of Vienna.

2013 Naturforscher, Weltreisende und nationale Forschungstraditionen: Bemerkungen zur Ethnologischen Erforschung Sibiriens im 18. und 19. Jahrhundert. In KaSTEN, Erich (ed) Reisen an den Rand des Russischen Reiches: die wissenschaftliche Erschließung der nordpazifischen Küstengebiete im 18. und 19. Jahrhundert, 11-28. Fürstenberg/Havel: Verlag der Kulturstiftung Sibiren.

SIPöcz, Katalin

2010 Munkácsi Bernát vogulföldi gyüjtése. A jelenkor feladatai és lehetőségei [Bernát Munkácsi's Fieldwork in the Land of the Voguls. The Tasks and Possibilities of our Days]. Nyelvtudományi Közlemények 107:276-283.

SkED, Alan

1979 The Metternich System, 1815-48. In SkED, Alan (ed) Europe's Balance of Power 1815-1848, 98-121. London: Macmillan.

2001 The Decline and Fall of the Habsburg Empire 1815-1918. London: Longman. SLEZKINE, Yuri

1994 Naturalists Versus Nations: Eighteenth-Century Russian Scholars Confront Ethnic Diversity. Representations 47:170-195. 
SLOBODNÍK, Martin

2012 Early Contacts between the Austro-Hungarian Empire and China: The Zichy Brothers in East Asia. In FindeISEN, Raoul David- Slobodník, Martin (eds) Talking Literature Essays on Chinese and Biblical Writings and Their Interaction, 101-122. Wiesbaden: Harrasowitz Verlag.

SPENCER, Frank

1979 Aleš Hrdlička M.D., 1869-1943: A Chronicle of the Life and Work of an American Physical Anthropologist (2 volumes). Michigan: University of Michigan.

STAUd, Géza

1999 Az orientalizmus a magyar romantikában [Orientalism in Hungarian

Stein, Aurél Romantic]. Budapest: Terebess.

1909 Közép-ázsiai utam, 1906-1908 [My Travels in Inner-Asia, 1906-1908]. Budapest: Lampel.

1986 Ázsia halott szívében. Válogatott írások [Travels in Asia’s Dead Heart. Selected Essays] Budapest: Helikon Kiadó.

2010 Indiából Kínába. Nagy Sándor nyomában Indiába [From India to China. Following the Footsteps of Alexander the Great]. Budapest: Palatinus Kiadó.

STEWART, Gordon

2014 The Exploration of Central Asia. In Kennedy, Dane (ed) Reinterpreting Exploration. The West in the World, 195-213. Oxford: Oxford University Press.

STIPA, Günther Johannes

1990 Finnisch-ugrische Sprachforschung: von der Renaissance bis zum Neupositivismus. (Suomalais-Ugrilaisen Seuran Toimituksia, 206 / Mémoires de la Société Finno-Ougrienne, 206.) Helsinki: Suomalais-Ugrilainen Seura.

Stoffa, Pál

1935 Menekülés öt világrészen át [Escape through Five Continents]. Budapest: Királyi Magyar Egyetemi Nyomda.

SugAR, Peter F.

1969 External and Domestic Roots of Eastern European Nationalism. In SugAR, Peter F. -Lederer, Ivo J. (eds) Nationalismus in Eastern Europe, 45-54. Seattle - London: University of Washington Press.

SUNDHAUSEN, Holm

1973 Der influss der Herderischen Ideen auf die Nationalsbildung bei der Völkern den Habsburgermonarchie. München: Oldenbourg.

SZÉCHENYI, BÉLA

1990 Gróf Széchenyi Béla keletázsiai útjának tudományos eredménye, 1877-1880, I. Budapest: Kilián

Sz. KRISTÓF, Ildikó

2011 The Uses of Natural History. Georg C. Raff's Naturgeschichte für Kinder (1778) in its Multiple Translations and Multiple Receptions. In ADAMs, Alison - Ford, Philip (eds) Le livre demeure. Studies in Book History in Honour of Alison Saunders, 309-333. Genève: Droz. 
2012 Missionaries, Monsters, and the Demon Show. Diabolized Representations of American Indians in Jesuit Libraries of $17^{\text {th }}$ and $18^{\text {th }}$ Century Upper Hungary. In KÉRCHY, Anna - ZitTlau, Andrea (eds) Exploring the Cultural History of Continental European Freak Shows and 'Enfreakment', 38-73. Newcastle upon Tyne: Cambridge Scholars Publishing.

2013 Domesticating Nature, Appropriating Hierarchy: The Representation of European and Non-European Peoples in an Early-Nineteenth-Century Schoolbook of Natural History. In Demski, Dagnosław - Sz. KristóF, Ildikó - BaranieczKa-Olsewska, Kamila (eds) Competing Eyes. Visual Encounters with Alterity in Central and Eastern Europe, 40-66. Budapest: L'Harmattan.

2014a Local Access to Global Knowledge: Historia Naturalis and Anthropology at the Jesuit University of Nagyszombat (Trnava), as Transmitted in its Almanacs (1676-1709). In Almási, Gábor (ed) A Divided Hungary in Europe, vol. 1: Study Tours and Intellectual-Religious Relationships, 201-228. Newcastle: Cambridge Scholars Publishing.

2014b The Representation of the Australian Aborigines in Text and Picture: Dr. Med. Pál Almási Balogh (1794-1863) and the Birth of the Science of Anthropology in Central Europe/Hungary. In Csúri, Piroska - GArcía Ferrari, Mercedes (eds) Caiana Revista academica de Historia del Arte y Cultura Visual de Centro Argentino de Investigadores de Arte (CAIA), 126-140. Buenos Aires: Segundo semestre, 2014, dossier special: "Ciencia y Cultura Visual”.

2016 „Terepmunka” a Terepmunka kora elött: Dobosy Mihály, a grönlandi inuitok és az etnológia (antropológia) születése a 19. század eleji Magyarországon ["Fieldwork" before the Age of Fieldwork: Mihály Dobosy, the Greenland Inuit and the Emergence of the Science of Ethnology/Anthropology in Hungary]. Ethno-lore 32:1-23.

2017 Alexander von Humboldt és Magyarország. Egy romantikus természettudós jelentősége a magyarországi egyetemes néprajzi érdeklődés kibontakozásában [Alexander von Humboldt and Hungary, the Importance of a Romantic Scientist in Hungary's Rising Interest in Universal Ethnography]. Századok 151(5):987-1006.

SzARKA, László

1998 Magyarosodás és magyarosítás a kiegyezés korában [Assimilation and Magyarization in the Age of the Dualist Monarchy]. In SzARKA, László (ed) Duna-táji dilemmák. Nemzeti kisebbségek - kisebbségi politika a 20. századi Kelet-Közép-Európában, 33-73. Budapest: Ister.

SzÍJ, Enikő

2009 Reguly Antal életpályája [The Career of Antal Reguly]. Nyelvtudományi Közlemények 106: 283-289.

2013 Reguly és a tudomány „,zománcza”: Életrajzi és kortörténeti adalékok [Reguly and the „Glaze” of Science: Biographic and Historical Addenda]. Budapest: SzUK, Géza

Finnugor Népek Világkongresszusa Magyar Nemzeti Szervezete.

1904 A mi Kis Khinánk [Our Little China]. Vasárnapi Ujság 18(51):292-294. 
SzÜCS, Jenő

1985 Történeti „eredet” kérdések és a nemzeti tudat [Questions of Historical "Origin" and National Identity]. Valóság 28(3):31-49.

TARDY, Lajos

1975 A naiv őshazakutatás múltjából. AXIX. század első felében Oroszországban élt magyarok néhány levele [On the History of Naïve Research on the Homeland of Hungarians. Letters from Russia from the Early $19^{\text {th }}$ Century]. Keletkutatás 3(1):153-161.

ThOMAs, Nicholas

1994 Colonialism's Culture. Anthropology, Travel and Government. Cambridge: Polity Press.

TOLDY, Ferenc

1850 Reguly Antal [Antal Reguly]. In Toldy, Ferenc (ed) Reguly-Album. Történeti es szépirodalmi tartalommal Jászai, Jósai, Jósika, Lugossy, Petöfi, Rischel, Sziglegeti, Vahot I. és Venczel által Megelözik Reguly utazásai Toldy Ferencztöl, V-CLVV. Budapest: Emich Gusztáv.

TODOROvoví, Jiřina - CHOVANEČEK, Jan

2011 Kolem světa, Sbirka fotografii z cest Josefa ořenského v Náprstkově muzeu asijských, afrických a amerických kultur [Around the World. Josef Kořenský's Travels Photograph Collection from Náprstek Museum of Asian, African and American Culture]. Praha: Národní muzeum.

Ujfalvy de Mezö-Kövesd, Charles

1878-1880 Expédition scientifique française en Russie, en Sibérie et dans le Turkestan $I-V I$. Paris: Ernest Leroux.

UjFaLVy - Bourdon, Mária

1885 Ujfalvy Károly utazása Páristól-Samarkandig. A Ferganah, Kuldzsa és VÁMBÉRY, Ármin nyugati Szibéria. Egy párizsi nö úti élményei. Budapest: Révai.

1871 Oroszország hatalmi állása Ázsiában [Russia’s Power Relations in Asia]. Budapest: Athenaeum.

1966 Dervisruhában Közép-Ázsián át [Crossing Central-Asia in Dervish Garment]. Lektorálta: Kakuk Zsuzsa. Budapest: Gondolat.

2014 Küzdelmeim. Életrajzok, emlékiratok [Struggles. Biographies, Memoirs]. Budapest: Fapadoskönyv.hu.

VARGA, Bálint

2017 Árpád a város felett. Nemzeti integráció és szimbolikus politika a 19. század végének Magyarországán [Árpád above the City. National Integration and Symbolic Politics in the Late $19^{\text {th }}$ Century Hungary]. Budapest: MTA Bölcsészettudományi Kutatóközpont Történettudományi Intézet.

VÁRKonYI, Ágnes

1973 A pozitivista történelemszemlélet a magyar történetírásban I-II. [The Positivist Approach to History in Hungarian Historiography I-II]. Budapest: Akadémiai Kiadó.

VAY, Péter

1906 Kelet császárai és császárságai [Emperors and Empires of the Orient]. Budapest: Franklin-Társulat. 
1918 A keleti féltekén [At the Eastern Hemisphere]. Budapest: Franklin-Társulat. VERMEUlen, Han F.

2008 Early History of Ethnography and Ethnology in the German Enlightenmen: Anthropological Discourse in Europe and Asia, 1710-1808. Leiden: Ridderprint.

2015 Before Boas. The Genesis of Ethnography and Ethnology in the German Enlightenment. Lincoln-London: University of Nebraska Press.

WANDRUSZKA, Adam

1980 'Notwendiger Völkerverein' oder 'Völkerkerker'. In WANDRUSZKA, Adam URBANITSCH, Peter (eds) Die Habsburgermonarchie 1848-1918, vol. III, xiiixviii Wien: Verlag der Österreichischen Akademie der Wissenschaften.

WiLManns, Karl

1995 Lues, Lamas, Leninisten. Tagebuch einer Reise durch Rußland in die Burjatische Republik im Sommer 1926. Pfaffenweiler: Centaurus VerlagGesellschaft.

Wintermantel Péter

1999 Szemere Attila hagyatékának orientalisztikai vonatkozású anyagai [Oriental Objects from Attila Szemere's Heritage] Herman Ottó Múzeum Évkönyve 38:793-814.

WoOLF, Stuart (ed)

1996 Nationalism in Europe, 1815 to the present. London: Routledge.

Youngs, Tim

2006 Travel Writing in the Nineteenth Century. Filling the Blank Spaces. London: Anthem Press.

ZEMAN, Adolf

1923 V kraji šamanů a lamů: Obraz života mongolských Burjati̊ [In the Country of Shamans and Lamas: Pictures from Mongol Buryat's Life]. Praha: Památník odboje.

ZEMAN, Adolf

1928 O Bajkalu, Zabajkalí a Burjatech [About Lake Baikal, Trans-Baikalia and the Buryats]. In Zeman, Adolf (ed) Cestami odboje (jak žily a kudy táhly čs. legie)

ZichY, Ágost dil IV. Anabáze, 215-223. Praha: Památník odboje.

1877 Utazás Pekingből a mongol sivatagon át Urgába [Travel from Peking to Urga Crossing the Mongolian Desert]. Földrajzi közlemények 5:8-48.

1880 Úti emlékek Chínából [Travel Memoirs from China]. Budapesti Szemle 44:296-327.

ZICHY, Jenő

1897 Zichy Jenö gróf kaukázusi és középázsiai utazásai. Voyages au Caucase et en Asie centrale. Budapest: Gustave Ranschburg.

1905 Zichy Jenö gróf Harmadik ázsiai utazása [The Third Asian Journey of the Count Jenő Zichy]. Tom VI. Budapest: Hornyánszky. 
ZichY, Mihály (ed)

2013 Gróf Zichy József utazásai I-II. (Ázsiai útinapló 1875-76; Amerikai útinapló 1877) [Count Joseph Zichy's Journeys I-II, Asian Travel Diary 1875-76; American Travel Diary 1877]. Budapest: Széphalom Könyvmühely - Országos Széchényi Könyvtár.

Csaba Mészáros is a research fellow at the Institute of Ethnology, Research Centre for the Humanities, Hungarian Academy of Sciences. He has conducted multiple fieldworks since 2002 in Northeastern Siberia among Sakhas.

Stefan Krist is an assistant professor at the Center for Mongolian Studies at the Innner Mongolia University in Hohhot, China. He has conducted multiple fieldworks and archival research in the Republic of Buryatia in Southern Siberia as well as in Moscow, St. Petersburg, and elsewhere.

Vsevolod Bashkuev is a senior research fellow at the Institute of Mongolian, Buddhist and Tibetan Studies of the Siberian Branch of the Russian Academy of Sciences. He researches the history of European medicine in Buryatia, Mongolia, Tuva and Xinjiang in the late nineteenth - early twentieth centuries.

Luboš Bělka is an associate professor at the Department for the Study of Religions, Faculty of Arts, Masaryk University. He has conducted multiple fieldwork research in the Republic of Buryatia in Southern Siberia.

Zsófia Hacsek obtained her MA degree in Social and Cultural Anthropology at the University of Vienna. She has conducted fieldworks and archival researches in ethnohistory, historical anthropology and migration/refugee studies.

Zoltán Nagy is a professor at the Department of European Ethnology and Cultural Anthropology of the University of Pécs, Hungary. He has conducted multiple fieldworks since 1992 in Western Siberia among Khanties.

István Sántha is a senior research fellow at the Institute of Ethnology, Research Centre for the Humanities, Hungarian Academy of Sciences. He has conducted social anthropological fieldwork in the Baikal region, and carried out research on the history of Hungarian Orientalics.

Ildikó Sz. Kristóf is a senior research fellow at the Institute of Ethnology, Research Centre for the Humanities, Hungarian Academy of Sciences, Budapest. She has been pursuing archival research on the early modern history of ethnology and anthropology in Hungary, with special attention to America and Jesuit learning. 